\title{
PENGARUH BIDANG KEAHLIAN GURU DALAM PEMBELAJARAN TERHADAP PENGEMBANGAN KARAKTER SISWA
}

\author{
${ }^{1}$ Saprya, Prodi Pendidikan IPS, FPIPS, UPI \\ ${ }^{2}$ Erlina Wiyanarti, Prodi Pendidikan IPS, FPIPS, UPI \\ ${ }^{3}$ Muhamad Iqbal, Prodi Pendidikan IPS, FPIPS, UPI
}

\begin{abstract}
ABSTRAK
Guru sebagai juru taman memiliki makna yang mendalam, yang mana taman akan diolah menjadi tandus atau subur tergantung dari bagaimana seorang guru dapat mengelola taman tersebut. Taman disini kalau diibaratkan sebagai siswa yang berada di dalam kelas, maka memiliki arti bahwa baik dan tidaknya kelas tersebut tergantung dari guru yang memiliki kewenangan untuk mengelola kelas dengan baik. Begitu juga dengan pengembangan karakter bagi siswa dibutuhkan figur teladan yang dimiliki oleh guru dengan bidang keahlian yang sesuai dengan tuntutan materi pembelajarannya. Namun sayangnya, masih banyak yang menganggap bahwa pendidikan karakter hanya cukup diajarkan sebatas pengetahuan. Hal ini mengakibatkan pendidikan karakter seolah-olah terasa hambar dan cenderung membosankan. Oleh karena itu dibutuhkan sosok guru teladan yang memiliki keahlian dalam pembelajaranlah yang akan mampu menjadikan peserta didik yang berkarakter.
\end{abstract}

Kata kunci: karakter, keahlian guru, pengelolaan kelas.

\section{PENDAHULUAN}

Ditegaskan dalam Peraturan Mendiknas Nomor 22 tahun 2006 tentang Standar Isi Pendidikan Dasar dan Menengah yang menyebutkan bahwa mata pelajaran IPS di SMP secara rinci memiliki 4 tujuan, yaitu: a) mengenal konsep-konsep yang berkaitan dengan kehidupan masyarakat dan lingkungan; b) memiliki kemampuan dasar untuk berpikir logis dan kritis, rasa ingin tahu, inkuiri, memecahkan masalah dan keterampilan dalam kehidupan sosial; c) memiliki komitmen dan kesadaran terhadap nilai-nilai sosial dan kemanusiaan; d) memiliki kemampuan berkomunikasi, bekerjasama dan berkompetensi dalam masyarakat yang majemuk baik ditingkat lokal, nasional dan global.

Kemudian Jarolimek (1993: 8) yang mengharapkan pendidikan IPS mampu mengembangkan aspek pengetahuan dan pengertian (knowledge and understanding), aspek sikap dan nilai (attitude and value), serta aspek keterampilan (skill) pada diri siswa. Aspek pengetahuan dan pengertian berkaitan dengan pemberian bekal pengetahuan dan pemahaman siswa tentang dunia dan kehidupan masyarakat di sekitarnya, aspek sikap dan nilai berkaitan dengan pemberian bekal mengenai dasar-dasar etika dan norma yang nantinya menjadi orientasi nilai dalam kehidupannya di masyarakat. Sedangkan aspek keterampilan meliputi keterampilan sosial (social skill) dan keterampilan intelektual (intellectual skill) agar siswa tenggap terhadap permasalahan sosial di sekitarnya dan mampu bekerjasama dengan orang laian dalam kehidupan sehari-hari. Sejalan dengan peraturan dan pandangan di atas, menurut DeRoche, Sullivan dan Garret (1999) pendidikan karakter dibutuhkan karena:

Our young need character education to learn and practice those values inherent in this nation's founding documents. Schools need character education to become places where students construct their socio-moral selves; where they learn to reason critically and morally; and where they practice the habits and skills of being good people and good citizens. 
Dari kutipan di atas dapat kita ketahui bahwa pendidikan karakter dibutuhkan oleh pemuda kita untuk belajar dan praktik nilai-nilai yang tidak bisa dipisahkan dalam dokumen pendirian bangsa. Sekolah memerlukan pendidikan karakter agar para siswa membangun moral sosial mereka sendiri; dimana mereka belajar untuk memberi alasan dengan kritis dan secara bermoral; dan dimana mereka praktik kebiasaan dan keterampilan menjadi orang baik dan warga negara yang baik.

Namun pada kenyataannya, masih banyak kelemahan-kelemahan yang dimiliki guru sehingga nilai-nilai tersebut belum seutuhnya dapat dilaksanakan. Kelemahan tersebut diantaranya seperti masih banyaknya tenaga pengajar yang tidak sesuai dengan bidang keahlian dalam mengajar, IPS masih dianggap oleh sebagian besar siswa sebagai mata kuliah yang membosankan seperti siswa tidak dilibatkan dalam proses pembelajaran serta buku paket sebagai satu-satunya sumber belajar. Seperti yang diungkap oleh Sanusi (1998), pembelajaran IPS di sekolah melahirkan output instrumental yang tidak kuat (not powerfully instrumental output), tidak mampu memberikan peluang kepada siswa untuk memberdayakan dirinya, lebih banyak didasarkan atas kebutuhan formal daripada kebutuhan real siswa serta sangat menjemukan dan membosankan.

Untuk mencapai amanat undang-undang tersebut, dalam upaya pencapaian tujuan pendidikan maka dibutuhkan peran profesional guru. Guru merupakan pendidik profesional dengan tugas utama mendidik, melatih, mengajar, membimbing, mengarahkan, melatih, menilai, dan mengevaluasi peserta didik. Profesional adalah pekerjaan atau kegiatan yang dilakukan seseorang dan menjadi sumber utama penghasilan kehidupan yang memerlukan keahlian, kemahiran, atau kecakapan yang memenuhi standar mutu atau norma tertentu serta memerlukan pendidikan profesi.Keadaan ideal tersebut tentu saja dapat menjadi cerminan betapa dekatnya pendidikan dengan pengembangan karakter. Di lapangan, keadaan tersebut jauh berbeda. Hal tersebut dapat diindikasikan dengan guru-guru pengajar yang di luar bidang keahlian; seperti guru IPS yang bidang keahliannya justru di luar IPS belum memiliki kemahiran dan kecakapan dalam pengajaran.

Dalam konteks program pembelajaran, tanpa mengurangi arti penting serta tanpa mengesampingkan faktor-faktor yang lain, faktor kualitas pembelajaran merupakan faktor yang sangat berperan dalam meningkatkan hasil pembelajaran yang pada akhirnya akan berujung pada meningkatnya kualitas pendidikan, karena muara dari berbagai program pendidikan adalah pada terlaksananya program $p$ embelajaran yang berkualitas. Menurut Clark (1981: 12) hasil belajar siswa di sekolah $70 \%$ dipengaruhi oleh kemampuan siswa dan $30 \%$ dipengaruhi oleh lingkungan. Sedangkan salah satu lingkungan belajar yang paling dominan mempengaruhi hasil belajar di sekolah adalah kualitas pembelajaran (Nana Sudjana, 2002: 40). Oleh karena itu untuk mengevaluasi keberhasilan program pembelajaran tidak cukup hanya berdasarkan pada asil penilaian hasil belajar siswa semata, namun perlu juga memperhatikan hasil penilaian terhadap input serta evaluasi terhadap kualitas pembelajaran.

Dengan demikian, guru mempunyai andil yang sangat besar dalam menentukan dapat dikembangkan atau tidaknya pendidikan karakter tersebut dalam pelajaran Ilmu Pendidikan Sosial (IPS). Sehingga dari uraian di atas, peneliti sangat tertarik untuk mengkaji bagaimana pengaruh bidang keahlian Guru IPS terhadap pengembangan karakter siswa di SMP se-Jawa Barat.

\section{METODE PENELITIAN}

Lokus penelitian ini di SMP yang berada di lingkungan Jawa Barat. Hasil perhitungan dalam menentukan sampel minimal dengan menetapkan presisi sebanyak $10 \%(0,1)$. Oleh karena itu, sampel yang diambil minimal 100 responden.

Populasi dalam penelitian ini adalah Sekolah Menengah Pertama 3.462 SMP yang terdiri dari 1.577 SMP Negeri dan 1.885 SMP Swasta. Dari hasil penentuan sampel minimal, perlu menentukan jumlah responden yang terpilih berdasarkan Wilayah. Penentuan sampel dengan menggunakan Complex Sampling dari 
data wilayah yang terdiri dari 26 kota/kabupaten dengan jumlah 3.462 SMP yang terdiri dari 1.577 SMP Negeri dan 1.885 SMP Swasta, wilayah secara berurutan berada pada posisi tengah 35.

Penelitian ini menggunakan pendekatan kuantitatif melalui metode survei (dominan) karena sebagian besar data diperoleh secara kuatitatif. Pendekatan kuantitatif dengan maksud untuk menelaah variabel-variabel yang signifikan baik secara parsial maupun simultan tentang pengaruh bidang keahlian guru dan metode pembelajaran terhadap pengembangan karakter siswa SMP Jawa Barat. Berdasarkan permasalahan dan karakteristik objek telaahan penelitian, maka penelitian ini menggunakan metode survei, menurut Kline sebagaimana dikutif Sugiyono (2005: 7) mengemukakan bahwa:

Metode survei pada umumnya dilakukan untuk mengambil suatu generalisasi dari pengamatan yang tidak mendalam.Walaupun metode survei ini tidak memerlukan kontrol seperti halnya pada metode eksperimen, namun generalisasai yang dilakukan bisa lebih akurat bila digunakan sampel yang refresentatif.

Analisis kuantitatif dilakukan untuk data yang terkumpul melalui angket, dengan menggunakan analisis statistik korelasi dan regresi (Sugiyono;2005).

\section{PEMBAHASAN PENGARUH BIDANG KEAHLIAN GURU IPS TERHADAP PENGEMBANGAN KARAKTER SISWA DI SMP SE-JAWA BARAT}

Berikut tabel dan deskripsi hasil Penelitian mengenai pengaruh bidang keahlian guru IPS terhadap pengembangan karakter siswa di SMP Se-Jawa Barat.

\begin{tabular}{|c|c|c|c|c|c|}
\hline \multicolumn{6}{|c|}{ Pendidikan ter ak hir anda SMA } \\
\hline & & Frequency & Percent & Valid Percent & $\begin{array}{c}\text { Cumulative } \\
\text { Percent }\end{array}$ \\
\hline \multirow[t]{4}{*}{ Valid } & 0 & 90 & 92,8 & 93,8 & 93,8 \\
\hline & 1 & 5 & 5,2 & 5,2 & 99,0 \\
\hline & 2 & 1 & 1,0 & 1,0 & 100,0 \\
\hline & Total & 96 & 99,0 & 100,0 & \\
\hline Missing & System & 1 & 1,0 & & \\
\hline Total & & 97 & 100,0 & & \\
\hline
\end{tabular}

Berdasarkan hasil Penelitian diperoleh bahwa sebanyak 5,2\% guru SMP di Jawa Barat memiliki tingkat pendidikan SMA, sementara itu sebanyak $92,8 \%$ dan $1,0 \%$ memiliki tingkat pendidikan lainnya.

Pendidikan ter ak hir anda S1 deng an k onsentrasi Pendidikan IPS (pendidik an ekonomi/pendidik an sejarah, pendidikan ge ografi, pendidikan sosiologi, pendidik an antropologi)

\begin{tabular}{|ll|r|r|r|r|}
\hline & Frequency & \multicolumn{1}{|c|}{ Percent } & Valid Percent & \multicolumn{2}{c|}{$\begin{array}{c}\text { Cumulative } \\
\text { Percent }\end{array}$} \\
\hline Valid & 0 & 41 & 42,3 & 42,7 & 42,7 \\
& 1 & 55 & 56,7 & 57,3 & 100,0 \\
& Total & 96 & 99,0 & 100,0 & \\
Missing & System & 1 & 1,0 & & \\
Total & & 97 & 100,0 & & \\
\hline
\end{tabular}

Tabel 2. menunjukkan bahwa sebanyak 55\% responden memiliki pendidikan terakhir S1 dengan konsentrasi Pendidikan IPS (Pendidikan ekonomi, pendidikan sejarah, pendidikan geografi, pendidikan sosiologi, dan pendidikan antropologi). Sementara itu sebanyak 42,3\% memiliki pendidikan terakhir $\mathrm{S} 1$ pada konsentrasi non-Pendidikan IPS.

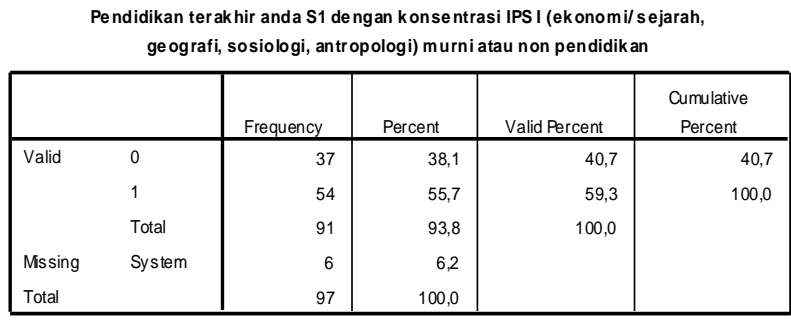

Tabel 3. menunjukkan bahwa sebanyak $55,7 \%$ responden memiliki pendidikan terakhir $\mathrm{S} 1$ dengan konsentrasi IPS (ekonomi, sejarah, geografi, sosiologi, dan antropologi) murni atau non pendidikan. Adapun sebanyak 37\% memiliki pendidikan terakhir S1 nonkonsentrasi IPS murni. Dengan demiksiswan bisa jadi persentase tersebut terdiri dari guru IPS SMP di Jawa Barat yang memiliki tingkat pendidikan SMA, S1 pendidikan IPS, S1 konsentrasi IPS, dan S1 dengan konsentrasi bukan IPS.

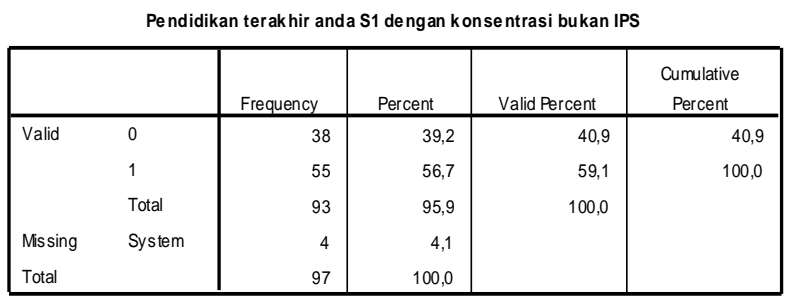

Data tersebut menunjukkan bahwa sebanyak $56,7 \%$ responden memiliki pendidikan terakhir dengan konsentrasi bukan IPS. Sementara itu sebanyak 39,2\% memiliki pendidikan terakhir S1 dengan konsentrasi bukan IPS. 


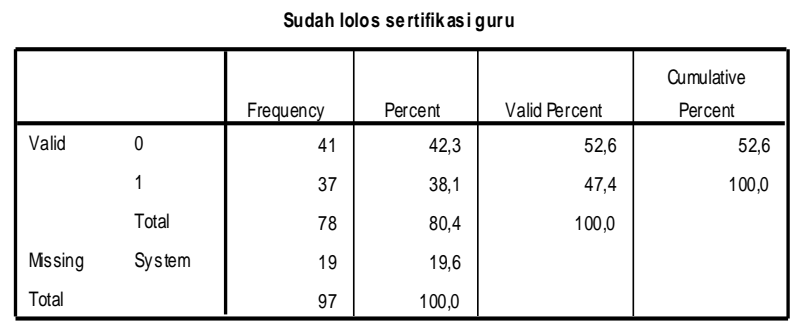

Berdasarkan tabel tersebut diperoleh gambaran bahwa responden sebanyak $38,1 \%$ sudah lolos sertifikasi guru, sementara itu $42,3 \%$ belum lolos sertifikasi guru.

\begin{tabular}{|c|c|c|c|c|c|}
\hline \multicolumn{6}{|c|}{ Pernah mengikuti seminar/pelatihan terkait Pendidikan IPS } \\
\hline & & Frequency & Percent & Valid Percent & $\begin{array}{c}\text { Cumulative } \\
\text { Percent }\end{array}$ \\
\hline \multirow[t]{3}{*}{ Valid } & 0 & 42 & 43,3 & 44,2 & 44,2 \\
\hline & 1 & 53 & 54,6 & 55,8 & 100,0 \\
\hline & Total & 95 & 97,9 & 100,0 & \\
\hline Missing & System & 2 & 2,1 & & \\
\hline Total & & 97 & 100,0 & & \\
\hline
\end{tabular}

Tabel di atas menunjukkan bahwa sebagian besar responden pernah mengikuti seminar/ pelatihan terkait pendidikan IPS yaitu sebanyak $54,6 \%$. Sementara itu sebanyak $43,3 \%$ tidak pernah mengikuti seminar/pelatihan terkait pendidikan IPS. Data tersebut menunjukkan bahwa sebagian besar guru IPS di SMP Jawa Barat memiliki bekal tambahan untuk peningkatan profesionalismenya selain kegiatan belajar mengajar di kelas.

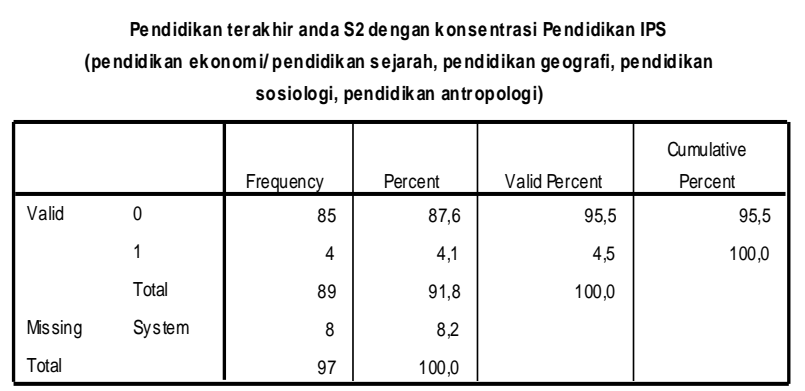

Data tersebut menunjukkan bahwa sebagian besar responden / guru IPS SMP di Jawa Barat tidak mengenyam pendidikan S2 dengan konsentrasi pendidikan IPS (pendidikan ekonomi, pendidikan sejarah, pendidikan geografi, pendidikan sosiologi, pendidikan antropologi) yaitu sebanyak $87,6 \%$. Sementara itu guru IPS SMP di Jawa Barat yang memiliki pendidikan terakhir S2 dengan konsentrasi pendidikan IPS sebanyak $4,1 \%$.

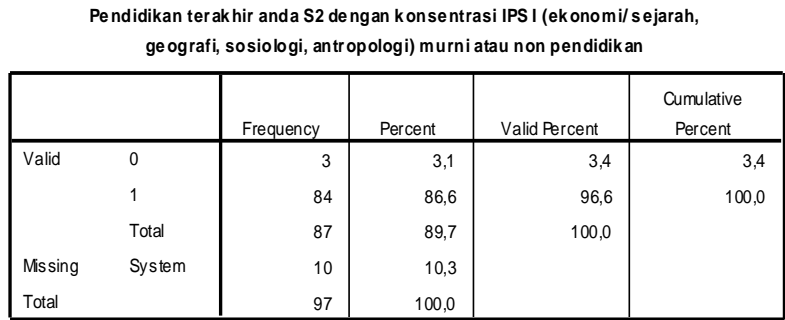

Data tersebut menunjukkan bahwa sebagian besar responden / guru IPS SMP di Jawa Barat mengenyam pendidikan S2 dengan konsentrasi IPS (ekonomi, sejarah, geografi, sosiologi, antropologi) murni atau nonkependidikan yaitu sebanyak $86,6 \%$. Sementara itu sebanyak 3,0\% tidak berlatarbelakang pendidikan S2 dengan konsentrasi IPS murni atau non-kependidikan.

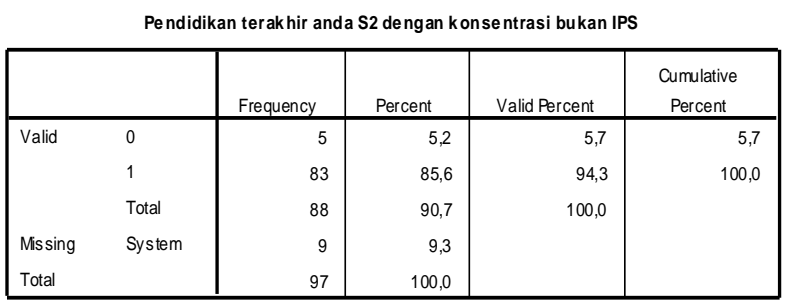

Data tersebut menunjukkan sebagian besar responden berlatarbelakang pendidikan terakhir S2 dengan konsentrasi bukan IPS yaitu sebanyak $83 \%$, sementara itu 5\% responden berlatarbelakang pendidikan terakhir S2 konsentrasi IPS.

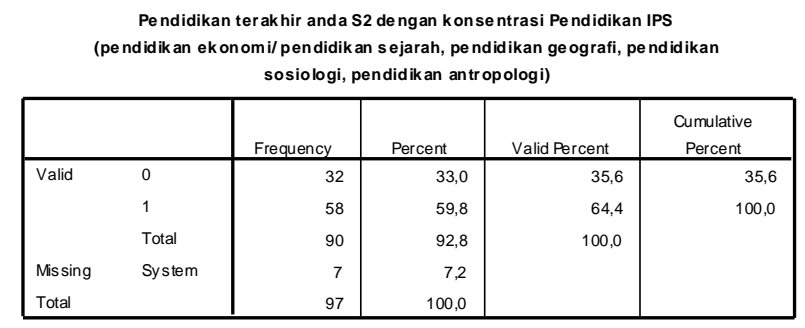

Tabel di atas menunjukkan bahwa responden sebanyak $58 \%$ berlatarbelakang pendidikan terakhir S2 dengan konsentrasi pendidikan IPS (pendidikan ekonomi, pendidikan sejarah, pendidikan geografi, pendidikan sosiologi, pendidikan antropologi). Sementara itu sebanyak $32 \%$ bukan berlatarbelakang S2 konsentrasi Pendidikan IPS. Berdasarkan penghitungan statistik dalam Penelitian ini ternyata terdapat pengaruh bidang keahlian guru IPS terhadap pengembangan karakter siswa di SMP se-Jawa Barat sebesar 0,216\% atau pada tingkatan rendah. 
Berdasarkan penghitungan statistik dalam Penelitian ini ternyata terdapat pengaruh bidang keahlian guru IPS terhadap pengembangan karakter siswa di SMP se-Jawa Barat sebesar $\mathbf{0 , 2 1 6 \%}$ atau pada tingkatan rendah. Hal ini sesuai pendapat Guilford's Empirical Rule dimana $0,2<\mathrm{r} \leq 0,4$ pada kategori rendah. Salah satu faktor yang mempengaruhi kualitas pembelajaran adalah varsiswabel guru. Guru mempunyai pengaruh yang cukup dominan terhadap kualitas pembelajaran, karena gurulah yang bertanggung jawab terhadap proses pembelajaran di kelas, bahkan sebagai penyelenggara pendidikan di sekolah. Hasil Penelitian ini menunjukkan rendah karena sebagian besar guru IPS SMP Se-Jawa Barat pendidikan terakhirnya adalah SMA yaitu sebesar 92,8\%, guru IPS SMP se-Jawa Barat untuk kualifikasi pendidikan S1 dan S2 sebagian besar bukan dari pendidikan IPS tetapi ilmu sosial murni. Padahal, Penelitian yang dilakukan Heyneman \& Loxley (Dedi Supradi, 1999: 178) pada tahun 1983 di 29 negara menemukan bahwa di antara berbagai masukan (input) yang menentukan mutu pendidikan (yang ditunjukkan oleh prestasi belajar siswa) sepertiganya ditentukan oleh guru. Guru sebagai faktor dominan dalam melakukan pendidikan yang membangun karakter bangsa. Guru PIPS memiliki kontribusi baik pada tataran operasional untuk membangun karakter warga negara. Diakui bahwa pada dasarnya setsiswap mata pelajaran bertanggung jawab terhadap pembangunan karakter, namun secara historis, social studies telah banyak berperan dalam pengembangan dan penyelenggaraan untuk membentuk karakter warga Negara. Oleh karena itu, diperlukan guru IPS ahli dalam bidang IPS yang dapat dilihat dari kualifikasi pendidikan guru, konsentrasi pendidikan, \& pengembangan keprofesionalan.

Hasil Penelitian menunjukkan rendahnya pengaruh bidang keahlian guru IPS terhadap pembangunan karakter siswa SMP di Jawa Barat karena selain, kualifikasi pendidikan guru IPS sebagian besar SMA, konsentrasi pendidikan sebagian besar bukan dari pendidikan IPS yaitu sebesar 56,7\% memperkuat bagaimana guru membangun karakter siswa. Menggingat, membangun karakter itu tergantung juga kompetensi yang dimiliki oleh dosen.

Hasil Penelitian menunjukkan sebesar $38,1 \%$ guru IPS SMP Se-Jawa Barat yang telah mendapatkan sertifikasi. Undang-Undang Guru dan Dosen nomor 14 Tahun 2005 pasal 8 mengamanatkan bahwa guru wajib memiliki kualifikasi akademik, kompetensi, sertifikat pendidik, sehat jasmani dan rohani, serta memiliki kemampuan untuk mewujudkan tujuan pendidikan nasional.

Salah satu pengukuran dalam sertifikasi dosen adalah menunjukkan profesional. Guru adalah agen pembelajaran dan sekaligus sebagai agen pembentuk karakter bangsa. Pendidikan karakter mempunyai makna yang tinggi, karena pendidikan karakter dalam pembelajaran mampu menanamkan kebsiswasaan tentang hal yang baik, sehingga peserta didik menjadi paham tentang mana yang baik dan salah, mampu merasakan nilai yang baik dan mau melakukannya.

Pendidikan karakter merupakan sebuah proses panjang bahkan seumur hidup, maka hasil dari proses tersebut belum dapat dirasakan dalam waktu yang cepat seperti membalikkan telapak tangan. Usaha tersebut melibatkan semua pihak yang terlibat dalam pendidikan (di keluarga, sekolah, dan masyarakat). Pendidikan karakter memerlukan kontinyuitas dalam pembuatan, artinya untuk membentuk peserta didik yang berkarakter baik diperlukan memerlukan kontinyuitas dalam perbuatan, artinya untuk membentuk peserta didik yang berkarakter baik diperlukan upaya secara berkelanjutan/konsisten.

Berdasarkan analisa di atas dapat disimpulkan bahwa bidang keahlian dosen IPS SMP Se- Jawa Barat berpengaruh pada tingkatan rendah secara siginifikan terhadap pembangunan karakter siswa karena sebagian besar tamatan SMA dengan kualifikasi sarjana bukan dari pendidikan IPS.

\section{PENUTUP}

Berdasarkan sejumlah temuan dari hasil kajian yang telah dilakukan, maka penulis dapat menyimpulkan bahwa pembelajaran PIPS dan proses pembelajaran PIPS berpengaruh positif terhadap pembangunan karakter. Akan tetapi 
pada kenyataannya pembelajaran PIPS masih dihadapkan pada beberapa kondisi empirik yang sifatnya kotraproduktif dengan kedudukan pembelajaran PIPS sebagai wahana pembangunan karakter, diantaranya: masukan instrumental (instrumental input) terutama yang berkaitan dengan kualitas guru, keahlian bidang guru serta keterbatasan fasilitas dan sumber belajar; dan masukan lingkungan (enviromental input) terutama yang berkaitan dengan situasi dan kehidupan lingkungan di mana siswa berada. Oleh karena itu, setidaknya bidang keahlian dosen IPS SMP Se- Jawa Barat berpengaruh pada tingkatan rendah secara siginifikan terhadap pembangunan karakter siswa karena sebagian besar tamatan SMA dengan kualifikasi sarjana bukan dari pendidikan IPS.

\section{DAFTAR PUSTAKA}

Clark, R. \& Calvin B. (1981). Cognitive prescriptive theory and psycoeducational design. California: University of Southern.

Clark, R. \& Calvin B. (1981). Cognitive prescriptive theory and psycoeducational design. California: University of Southern

Cox , J. 2006. The quality of an instructional program. National Education

Association- Alaska. Diambil dari pada tanggal 23 Oktober 2006, dari

http://www.ak.nea.org./ excellence/coxquality.

Cruickshank, D.R. 1990. Research that informs teachers and teacher educators. Bicomington. Indiana: Phi Delta Kappa Educational Foundation.

Darling, L. \& Hammond. 2000. Teacher quality and student achievement: A R eview of state policy evidence.

Education Policy Analysis Archives. Volume 8 Number 1. Diambil pada tanggal 17 Juli 2006 dari http://epas.asu.edu/ epas/v8n1
Dedi Supriadi. 1999. Mengangkat citra dan martabat guru. Yogyakarta: Adicita Kar ya Nusa.

DeRoche, EF, Betty L Sulivan and Sherrye Dee Garrett. (1999). Character Matters: Using Newspapers to Teach Character. San Francisco: Use The News.

Jarolimek, j. 1993. Social Studies in Elementary Education. New York: Mac Millan,

Nana Sudjana. 2002. Dasar-dasar proses belajar dan mengajar. Bandung: Sinar Baru Algesindo.

Neni utami. 2003. Kualitas dan Profesionalisme Guru. Artikel diambil pada tanggal 12 September 2012.

Peraturan Mendiknas Nomor 22 tahun 2006 tentang Standar Isi Pendidikan Dasar dan Menengah.

Sanusi, A. (1998). Pendidikan alternatif. Bandung: Grafindo Media Pratama.

Sapriya. (2009). Pendidikan IPS. Bandung: Rosda Karya.

Schacter, J. 2006. Teacher performance-based accountability : why, what and how. Santa Moica : Miken Family Foundation. Diambil pada tanggal 15 Juli 2006 dari http://www.mff.org/pubs/ performanceassessment. pdf.

Somantri, M. N. (2001). Menggagas pembaharuan pendidikan IPS. Bandung: Remaja Rosdakarya \& PPs UPI Bandung.

Sugiyono. 2005. Statistik untuk Penelitian. Bandung: CV Alfabeta

Sukardi. (2004). Kajian kearifan lokal sasak dalam perspektif kajian pendidikan IPS. Mataram: FKIP Unram

Suwarma Al Muchtar. (1991). Pengembangan kemampuan berfikir dan nilai dalam pendidikan IPS (suatu studi budaya pendidikan). Disertasi Doktor tidak di publikasikan. Bandung: PPs IKIP Bandung.

Wesley, Edgar B. (1950). Teaching Social Studies in High School. Michigan: Heath, University of Michigan. 